Jurnal Agroteknologi, Vol. 10 No. 1, Agustus $2019: 23-32$

\title{
PERTUMBUHAN DAN HASIL JAGUNG MANIS (Zea mays Saccharata Sturt.) YANG DITANAM DENGAN TANAMAN SELA PEGAGAN (Centella asiatica (L.) Urban) PADA BEBERAPA TARAF DOSIS PUPUK ANORGANIK
}

\author{
(Growth and Yield of Sweet Corn (Zea mays Saccharata Sturt.) Grown Intercropping \\ With Pegagan Plants (Centella asiatica (L.) Urban) on Several Doses \\ of Inorganic Fertilizers)
}

\author{
SARJAN ALATAS, IRSYADI SIRADJUDDIN, MOKHAMAD IRFAN, AULIA RANI ANNISAVA \\ Program Studi Agroteknologi, Fakultas Pertanian dan Peternakan \\ Universitas Islam Negeri Sultan Syarif Kasim Riau \\ JI. H.R. Soebrantas No. 155 KM 18 Simpang Baru Panam Pekanbaru Riau 28293 \\ Email: sarjan.nemo@gmail.com
}

\begin{abstract}
The problem of agricultural crops cultivation today is the productivity of land that has not been optimally, where the availability of land among the main crops should be utilized maximally by planting intercrops. This research aims to determine the cropping patterns and the best of inorganic fertilizers dosage, well as the interaction of cropping patterns with inorganic fertilizer to the growth and yield of sweet corn. The research was conduted from November 2017 until January 2018 in the village of Dundangan, district of Pangkalan Kuras, Pelalawan regency and Agronomic Laboratory of Faculty of Agriculture and Animal Science, Universitas Islam Negeri Sultan Syarif Kasim Riau. This research uses Randomized Block Design (RBD) with two factors and three replications. The first factor is cropping pattern with two levels that is cropping pattern of sweet corn monoculture and cropping pattern of sweet corn with pegagan plant. The second factor is the application of inorganic fertilizers with three levels is $0 \%, 50 \%$ and $100 \%$ recommended dosage. The results showed that the cropping pattern of sweet corn planted with intercropping pegagan gave the same results as good with the croping pattern of sweet corn monoculture, except on the parameter of leaf age of 6 weeks after plant which yield more leaf number on monoculture cropping pattern. Inorganic fertilizers application 50\% recommended dosage (Urea $250 \mathrm{~kg} / \mathrm{ha}+T S P 175 \mathrm{~kg} / \mathrm{ha}+\mathrm{KCl} 150 \mathrm{~kg} / \mathrm{ha}$ ) increased yield weight of corn cobs weighted per plot, corn cob weight without weight per cob and weight of corn cobs without weight per plot.There is not interaction between cropping patterns and inorganic fertilizers on the growth and yield of sweet corn crops.
\end{abstract}

Keywords: Sweet corn, fertilizer, intercropping.

\section{PENDAHULUAN}

Tanaman jagung manis merupakan salah satu komoditas hortikultura yang telah banyak dibudidayakan. Hal ini dikerenakan jagung tersebut memiliki rasa lebih manis dan umur panen yang cepat dibandingkan jagung biasa. Tanaman jagung manis bila dikembangkan secara intensif oleh petani, maka akan menambah pendapatan karena permintaan yang cukup tinggi saat ini. Menurut Surtinah (2012), pasar jagung manis masih terbuka luas seiring dengan permintaan yang terus meningkat. Pusat Data dan Sistem Informasi Pertanian (2015), produksi jagung tahun 2014 kembali meningkat menjadi 19,009 juta ton atau naik sebesar $2,68 \%$ dan tahun 2015 kembali terjadi peningkatan yang cukup signifikan menjadi 20,667 juta ton atau naik sebesar $8,72 \%$. Meningkatnya permintaan pasar akan jagung manis harus diiringi dengan produksi secara berkesinambungan, hemat biaya dan efisien, serta ramah lingkungan

Permasalahan budidaya tanaman pertanian saat ini adalah produktivitas lahan yang belum optimal, dimana efisiensi lahan pertanian sangatlah diperlukan untuk menunjang efektivitas lahan, tanaman budidaya dan lingkungan. Budidaya tanaman jagung manis secara monokultur memiliki banyak faktor resiko, terutama pemanfaatan lahan produksi. BBPSLP (2011), diperkirakan 
terdapat 13,7 juta ha lahan potensial yang telah digunakan untuk keperluan nonpertanian, terutama untuk pemukiman, perkotaan dan infrastuktur. Ketersediaan lahan diantara tanaman jagung manis perlu dimanfaatkan secara maksimal dengan menanam tanaman sela. Salah satu tanaman yang potensial dijadikan tanaman sela adalah pegagan. Menurut Darwati dkk. (2012) tanaman pegagan akan tumbuh baik dengan intensitas cahaya $30-40 \%$, sehingga dapat dikembangkan sebagai tanaman sela misalnya diantara tanaman jagung, kelapa, kelapa sawit dan buah-buahan yang tidak terlalu rindang.

Keunggulan pegagan sebagai tanaman sela adalah adanya agensia hayati Fungi Mikoriza Arbuskula (FMA) yang bersimbiosis mutualistik dengan akar tanaman. Hasil penelitian Hartoyo (2012) menunjukkan, jenis FMA yang berhasil diisolasi dan diidentifikasi pada rizosfer tanaman pegagan pada tiga lokasi yang berbeda terdapat variasi tipe spora di Kebun Percobaan (KP) Cicurug terdapat 4 jenis FMA (Glomus sp-1, Glomus sp-2, Glomus sp-3 dan Acaulospora sp), di KP. Gunung Putri ditemukan 5 jenis FMA (Acaulospora sp, Glomus sp-1, Glomus sp-2, Glomus sp-3, dan Glomus sp-4), dan di KP. Sukamulya ditemukan 4 jenis FMA (Glomus $\mathrm{sp}-1$, Glomus sp-2, Glomus sp-3, dan Acaulospora sp).

Keunggulan lain penanaman pegagan sebagai tanaman sela adalah dapat menekan pertumbuhan gulma pada tanaman jagung manis. Keberadaan gulma akan berdampak negatif terhadap tanaman jagung akibat adanya persaingan faktor tumbuh. Menurut Mayadewi (2007) menyatakan, dalam suatu pertanaman sering terjadi persaingan antar tanaman maupun antara tanaman dengan gulma untuk mendapatkan unsur hara, air, cahaya matahari maupun ruang tumbuh. Menurut Bilman (2001), gulma yang dibiarkan tumbuh pada tanaman jagung manis dapat menurunkan hasil $20-80 \%$.

Selain pemanfaatan pegagan sebagai tanaman sela, pupuk juga berperan penting dalam keberhasilan budidaya tanaman pertanian. Menurut Nazirah (2014), salah satu upaya yang dapat dilakukan untuk menanggulangi kurangnya unsur hara tersebut adalah pemberian pupuk anorganik seperti Urea, TSP/SP-36 dan $\mathrm{KCl}$ yang sangat berpengaruh nyata terhadap tanaman, terutama pupuk Urea sehingga petani lebih cenderung menggunakan pupuk Urea dibandingkan pupuk TSP dan $\mathrm{KCl}$.

Penelitian ini bertujuan untuk mengetahui pola tanam dan dosis pupuk anorganik yang terbaik pengaruhnya, serta interaksinya terhadap pertumbuhan dan hasil tanaman jagung manis.

\section{BAHAN DAN METODE}

Penelitian ini dilaksanakan di Desa Dundangan, Kecamatan Pangkalan Kuras, Kabupaten Pelalawan, Provinsi Riau dan di Laboratorium Agronomi Fakultas Pertanian dan Peternakan Universitas Islam Negeri Sultan Syarif Kasim Riau. Waktu pelaksanaan penelitian pada bulan November 2017 sampai Januari 2018. Lokasi penelitian berada di dataran rendah dengan ketinggian $35 \mathrm{~m}$ dpl dan jenis tanahnya adalah mineral. Bahanbahan yang digunakan adalah bibit pegagan aksesi ungaran, benih jagung manis Varietas Bonanza F1, dolomit, Furadan 3G, pupuk kandang, pupuk Urea, TSP dan $\mathrm{KCl}$. Alat-alat yang digunakan adalah cangkul, parang, meteran, gunting, pisau, polybag, gembor, penggaris, kertas $\mathrm{pH}$, ember, tugal, timbangan digital, tali rafia, alat tulis, palu dan kamera.

Penelitian menggunakan Rancangan Acak Kelompok (RAK) terdiri dari 2 faktor dan 3 kelompok ulangan. Faktor pertama adalah pola tanam $(T)$ terdiri dari dua taraf yaitu: $T_{1}=$ Jagung manis monokultur dan $T_{2}=$ Jagung manis + tanaman sela pegagan. Faktor kedua yaitu pupuk anorganik (A) terdiri dari tiga taraf yaitu: $A 0=0 \%$ dosis rekomendasi (kontrol), $A_{1}$ $=50 \%$ dosis rekomendasi (Urea $250 \mathrm{~kg}+\mathrm{TSP}$ $175 \mathrm{~kg}+\mathrm{KCl} 150 \mathrm{~kg}$ ) per ha, dan $\mathrm{A}_{2}=100 \%$ dosis rekomendasi (Urea $500 \mathrm{~kg}+$ TSP $350 \mathrm{~kg}$ $+\mathrm{KCl} 300 \mathrm{~kg}$ ) per ha. Parameter yang diamati yaitu tinggi tanaman $(\mathrm{cm})$, panjang daun terpanjang $(\mathrm{cm})$, lebar daun terlebar $(\mathrm{cm})$, jumlah daun (helai), bobot tongkol jagung berkelobot per tongkol (g), bobot tongkol jagung berkelobot per plot $(\mathrm{kg})$, bobot tongkol jagung tanpa kelobot per tongkol (g), dan bobot tongkol jagung tanpa kelobot per plot $(\mathrm{kg})$, serta bobot basah tajuk tanaman $(\mathrm{g})$. Pengamatan tinggi tanaman dilakukan dengan cara mengukur dari permukaan tanah sampai ujung tertinggi tanaman, saat tanaman berumur 2 MST sampai muncul bunga jantan pada umur 42 HST dengan interval waktu pengukuran 2 minggu sekali. Pengamatan daun terpanjang dilakukan saat tanaman jagung berumur 2 minggu setelah tanam (MST) sampai muncul bunga jantan pada umur 42 HST, dengan cara mengukur dari pangkal sampai ujung daun. Pengamatan daun terlebar dilakukan dengan cara mengukur pada bagian tengah daun saat tanaman jagung berumur 2 MST sampai muncul bunga jantan pada umur 42 HST, menggunakan penggaris dan meteran dengan interval waktu pengukuran 2 minggu sekali. 
Pengamatan jumlah daun dilakukan dengan menghitung seluruh daun yang telah membuka secara sempurna. Pengamatan bobot tongkol jagung berkelobot per tongkol dilakukan dengan cara menimbang masingmasing tongkol jagung setiap sampel. Pengamatan bobot tongkol jagung berkelobot per plot dilakukan dengan cara menimbang tongkol jagung seluruh tanaman pada setiap plot. Pengamatan bobot tongkol jagung tanpa kelobot per tongkol dilakukan dengan cara menimbang tongkol jagung masing-masing sampel. Pengamatan bobot tongkol jagung tanpa kelobot per plot dilakukan dengan cara menimbang semua tongkol jagung pada setiap plot. Pengamatan bobot basah tajuk tanaman dilakukan dengan cara menimbang bagian tanaman setelah panen, kecuali bagian akar tanaman dengan memotong $\pm 10 \mathrm{~cm}$ dari pangkal batang.

\section{HASIL DAN PEMBAHASAN}

\section{Tinggi Tanaman Jagung Manis}

Hasil sidik ragam menunjukkan bahwa perlakuan pola tanam dan pupuk anorganik, serta interaksi keduanya tidak berpengaruh nyata terhadap parameter tinggi tanaman jagung manis pada setiap umur pengamatan (Tabel 1).

Tabel 1. Tinggi Tanaman Jagung Manis pada Umur 2 MST, 4 MST dan 6 MST

\begin{tabular}{cccc}
\hline Perlakuan & \multicolumn{3}{c}{ Tinggi Tanaman $(\mathrm{cm})$} \\
\cline { 2 - 4 } & 2 MST & 4 MST & 6 MST \\
\hline Pola Tanam (T) & & & \\
T1 & 22,180 & 150,368 & 234,406 \\
T2 & 23,028 & 143,618 & 221,959 \\
Pupuk Anorganik (A) & & & \\
A0 & 22,798 & 142,125 & 220,170 \\
A1 & 22,125 & 150,010 & 235,418 \\
A2 & 22,888 & 148,843 & 228,958 \\
\hline
\end{tabular}

Tabel 4.1 menunjukkan bahwa pada umur 2 MST sampai 6 MST, baik perlakuan pola tanam maupun aplikasi pupuk anorganik menghasilkan rata-rata tinggi tanaman yang tidak signifikan. Hal ini menandakan, bahwa pola tanam tumpangsari jagung manis yang ditambah aplikasi pupuk anorganik memberikan pertumbuhan tinggi tanaman yang sama baiknya dengan pola tanam monokultur. Diduga keberadaan pegagan sebagai tanaman sela tidak memberikan pengaruh kompetisi terhadap tanaman jagung manis dalam penyerapan unsur hara, melainkan memberikan respon positif dengan membantu penyerapan unsur hara, karena adanya simbiosis mutualistik fungi mikoriza arbuskula (FMA).

Hasil identifikasi FMA yang bersimbiosis dengan tanaman pegagan telah dilakukan peneliti sebelumnya. Hartoyo (2012) melakukan identifikasi FMA pada rizosfer tanaman pegagan pada 4 lokasi berbeda dan diperoleh 5 jenis FMA yaitu Glomus sp-1, Glomus sp-2, Glomus sp-3, Glomus sp-4 dan Acaulospora sp. Rumambi (2012), bahwa FMA jenis Glomus cukup baik kemampuannya di lapangan dan pembentukan spora juga sangat baik, sedangkan Acaulospora mempunyai kemampuan memperbanyak diri di dalam jaringan akar tanaman cukup tinggi.

Adanya simbiosis antara tanaman pegagan dengan FMA, akan memberikan keuntungan secara tidak langsung bagi tanaman jagung manis. Hal ini dikarenakan, kemampuan fungi mikoriza arbuskula (FMA) sebagai agen penyedia unsur hara yang sukar larut di dalam tanah menjadi mudah larut dan membantu tanaman dalam penyerapan unsur hara. Hartoyo (2012) menyatakan, simbiosis antara tanaman pegagan dengan FMA dapat terjalin jika kedua simbion tersebut mendapatkan manfaat dan menggunakan fungsi simbiosis secara maksimal. Menurut Farida (2011) tanaman yang bersimbiosis dengan CMA pertumbuhannya relatif lebih baik bila dibandingkan dengan tanaman yang tidak bersimbiosis dengan CMA. Pangaribuan (2014) menambahkan mikoriza berperan dalam peningkatan penyerapan unsur-unsur hara tanah yang dibutuhkan oleh tanaman seperti P, N, K, Zn, Mg, Cu dan Ca.

Penelitian sebelumnya juga menunjukkan, bahwa penanaman tanaman sela tidak mempengaruhi pertumbuhan pada tanaman utama. Hasil penelitian Mulyaningsih dan Hariyono (2013) menunjukkan penanaman tanaman sela kedelai, kacang hijau dan wijen diantara tanaman jarak pagar hasil rehabilitasi (penyambungan dengan IP2A) pada tahun ketiga tidak berpengaruh terhadap pertumbuhan tanaman jarak pagar. Menurut Aidid (2012) penanaman kol, caisin, wortel dan bawang daun sebagai tanaman sela pada tanaman pisang tanduk, tidak mempengaruhi pertumbuhan serta produksi pisang tanduk. 


\section{Panjang Daun Terpanjang}

Hasil sidik ragam menunjukkan, bahwa perlakuan pola tanam dan aplikasi pupuk anorganik serta interaksi keduanya tidak berpengaruh nyata terhadap panjang daun terpanjang tanaman jagung manis (Tabel 2).

Tabel 2. Panjang Daun Terpanjang pada Umur 2 MST, 4 MST dan 6 MST

\begin{tabular}{cccc}
\hline Perlakuan & \multicolumn{3}{c}{ Panjang Daun Terpanjang (cm) } \\
\cline { 2 - 4 } & 2 MST & 4 MST & MST \\
\hline Pola Tanam (T) & & & 106,419 \\
T1 & 24,168 & 92,419 & 102,819 \\
T2 & 24,576 & 88,902 & \\
Pupuk Anorganik (A) & & & 101,677 \\
A0 & 23,710 & 88,317 & 106,382 \\
A1 & 24,307 & 92,045 & 105,798 \\
A2 & 25,098 & 91,620 & \\
\hline
\end{tabular}

Tabel 2 menunjukkan bahwa perlakuan pola tanam dan aplikasi pupuk anorganik menghasilkan interval rata-rata panjang daun terpanjang tanaman jagung manis yang tidak signifikan. Hal ini menandakan bahwa perlakuan pola tanam jagung manis dengan atau tanpa tanaman sela pegagan yang diaplikasikan pupuk anorganik memberikan hasil yang sama baiknya terhadap parameter panjang daun terpanjang. Keberadaan tanaman sela pegagan pada areal tanaman jagung manis tidak memberikan efek kompetisi bagi tanaman utama. Diduga adanya perbedaan golongan tanaman C3 dan C4 yang berkaitan secara lansung terhadap proses fotosintesis tanaman.

Turmudi (2002) menyatakan bahwa jagung adalah tanaman golongan C4 menghendaki pencahayaan secara langsung, memiliki habitus tinggi, tegak dan tidak bercabang, dengan kanopi yang renggang memungkinkan tanaman ini memperoleh pencahayaan secara langsung dan dapat memberikan kesempatan bagi tanaman lain tumbuh dibawahnya. Menurut Martono (2011) tanaman pegagan merupakan tanaman C3 yang mempunyai tingkat kejenuhan cahaya lebih rendah dibandingkan tanaman C4, sehingga tanaman ini mempunyai peluang yang baik untuk dikembangkan pada kondisi intensitas cahaya rendah, misalnya sebagai tanaman sela semusim maupun tahunan.

Adanya simbiosis agensia hayati fungi mikoriza pada rizosfer tanaman pegagan diduga juga berperan dalam membantu tanaman melakukan penyerapan unsur hara di dalam tanah, yang secara tidak langsung akan memberikan keuntungan bagi tanaman lain yang berdekatan melalui kemampuan dalam translokasi hara. Hal ini sesuai dengan pernyataan Ingleby et al. (2007) bahwa fungi $G$. etunicatum syn. C. etunicatum dikenal sebagai salah satu FMA yang cepat berkembang membentuk jaringan bawah tanah yang menghubungkan rizosfer satu tanaman dengan tanaman lain, sehingga terjadi translokasi bahan dan energi di antara tanaman yang bertetangga. Allen dan Allen (1992), FMA dapat berperan penting dalam mempertahankan stabilitas keanekaragaman tanaman dengan cara transfer unsur hara dari satu akar ke akar tanaman lain yang berdekatan melalui struktur yang disebut hifa.

\section{Lebar Daun Terlebar}

Hasil sidik ragam menunjukkan bahwa perlakuan pola tanam dan aplikasi pupuk anorganik serta interaksi keduanya tidak berpengaruh nyata terhadap parameter lebar daun terlebar tanaman jagung manis pada setiap umur yang diamati (Tabel 3).

Tabel 3. Lebar Daun Terlebar pada Umur 2 MST, 4 MST dan 6 MST

\begin{tabular}{cccc}
\hline Perlakuan & \multicolumn{3}{c}{ Lebar Daun Terlebar (cm) } \\
\cline { 2 - 4 } & 2 MST & 4 MST & 6 MST \\
\hline Pola Tanam (T) & 3,338 & 9,440 & 10,289 \\
T1 & 3,203 & 9,156 & 9,978 \\
T2 & & & \\
Pupuk Anorganik (A) & 3,245 & 9,145 & 9,898 \\
A0 & 3,192 & 9,437 & 10,292 \\
A1 & 3,375 & 9,312 & 10,210 \\
A2 & & & \\
\hline
\end{tabular}


Tabel 3 menunjukkan bahwa perlakuan pola tanam dan aplikasi pupuk anorganik menghasilkan interval rata-rata lebar daun terlebar tanaman jagung manis yang tidak signifikan. Adanya tanaman sela pegagan pada areal tanaman utama jagung manis tidak menimbulkan kompetitor terhadap pertumbuhan vegetatif lebar daun tanaman jagung manis. Adanya mikoriza pada rizosfer tanaman pegagan menjadi keunggulan pada pola tanam tumpangsari dengan tanaman jagung manis. Diduga FMA turut berperan membantu penyediaan unsur hara di dalam tanah bagi tanaman jagung manis, sehingga pertumbuhan vegetatif tanaman jagung manis memberikan hasil yang sama baiknya dengan pola tanam monokultur. Menurut Rumambi (2012) terjadinya asosiasi tanaman jagung dengan FMA, sehingga terjadi peningkatan penyerapan hara mineral.

Infeksi FMA pada zona perakaran tanaman pegagan tergolong cukup tinggi dan infeksi tersebut tidak hanya terjadi pada tanaman induk saja, tetapi juga pada tanaman anakan. Rajapakse dan Miller (1992) menyatakan bahwa infeksi pada akar tanaman pegagan bermikoriza tergolong sangat tinggi $>75 \%$. Hartoyo (2012) menyatakan aktivitas FMA pada tanaman pegagan tidak hanya terjadi pada akar tanaman induk akan tetapi juga pada akar tanaman anakan.

\section{Jumlah Daun}

Hasil sidik ragam menunjukkan, bahwa perlakuan pola tanam berpengaruh nyata terhadap jumlah daun tanaman jagung manis pada umur 6 MST $(P>0,05)$ (Tabel 4).

Tabel 4. Jumlah Daun Tanaman Jagung Manis pada Umur 2 MST, 4 MST dan 6 MST

\begin{tabular}{cccc}
\hline Perlakuan & \multicolumn{3}{c}{ Jumlah Daun (helai) } \\
\cline { 2 - 4 } & 2 MST & 4 MST & 6 MST \\
\hline Pola Tanam (T) & 3,349 & 8,752 & $10,448^{\mathrm{a}}$ \\
T1 & 3,280 & 8,128 & $9,836^{\mathrm{b}}$ \\
T2 & & & \\
Pupuk Anorganik (A) & 3,210 & 8,377 & 9,710 \\
A0 & 3,335 & 8,628 & 10,192 \\
A1 & 3,398 & 8,315 & 10,523 \\
A2 & Superskrip yang berbeda pada lajur yang sama menunjukkan perbedaan yang nyata pada uji \\
& &
\end{tabular}

Tabel 4 menunjukkan bahwa pada umur 6 MST perlakuan pola tanam jagung manis monokultur (T1) menghasilkan nilai rata-rata jumlah daun terbanyak 10,448 helai dan berbeda nyata dengan perlakuan pola tanam jagung manis dan tanaman sela pegagan (T2) dengan rata-rata 9,836 helai. Berbedanya hasil jumlah daun tanaman jagung manis tersebut diduga tanaman sela pegagan memberikan persaingan menjelang akhir masa vegetatif tanaman jagung manis.

Menurut Hartoyo dkk. (2015) perilaku tumbuh tanaman pegagan adalah membentuk anakan atau stolon umumnya dimulai pada umur $30 \mathrm{HST}$, tergantung kondisi tanaman induk dan faktor lingkungan, yang selanjutnya akan memanjang horizontal dan tiap buku muncul akar disertai dengan munculnya tunas daun pada titik tumbuh, sehingga akan menjadi individu-individu baru terpisah dari tanaman utama. Individu-individu tersebut selanjutnya mengikuti perilaku tumbuh dari tanaman utamanya. Menurut Santoso (2004), peningkatan persaingan antar tanaman sejalan dengan semakin berkembangnya tanaman.

Peningkatan jumlah daun tanaman jagung manis diduga berkaitan dengan proses fisiologis tanaman terutama proses fotosintesis dan serapan unsur hara oleh akar tanaman.
Menurut Hasanah (2017) jumlah daun berhubungan dengan proses fotosintesis, semakin banyak jumlah daun, maka semakin banyak cahaya yang didapatkan tanaman, semakin tebal dan hijau daun, maka semakin banyak fotosintat yang diterima tanaman. Marlina dkk. (2016) menyatakan bahwa daun merupakan organ penting dalam proses fotosintesis dengan banyaknya jumlah daun maka semakin banyak jumlah daun yang aktif dalam melakukan proses fotosintesis.

\section{Bobot Tongkol Jagung Berkelobot Per Tongkol}

Berdasarkan hasil sidik ragam menunjukkan, bahwa aplikasi pupuk anorganik berpengaruh sangat nyata terhadap bobot tongkol jagung berkelobot per tongkol. Perlakuan $100 \%$ dosis rekomendasi (A2) memberikan hasil rata-rata bobot tongkol jagung berkelobot per tongkol tertinggi yaitu $359,112 \mathrm{~g}$, yang berbeda nyata dengan perlakuan $50 \%$ dosis rekomendasi (A1) dan $0 \%$ dosis rekomenasi $(\mathrm{A} 0)$ dengan nilai ratarata 327,530 g dan 257,033 g (Tabel 5). 
Tabel 5. Bobot Tongkol Jagung Berkelobot Per Tongkol (g)

\begin{tabular}{cc}
\hline Perlakuan & Bobot Tongkol Jagung Berkelobot Per Tongkol $(\mathrm{g})$ \\
\hline Pola Tanam (T) & 326,920 \\
T1 & 302,197 \\
T2 & \\
Pupuk Anorganik (A) & $257,033^{\mathrm{b}}$ \\
A0 & $327,530^{\mathrm{b}}$ \\
A1 & $359,112^{\mathrm{a}}$ \\
A2 &
\end{tabular}

Berdasarkan Tabel 5 menunjukkan bahwa aplikasi pemupukan $100 \%$ dosis rekomendasi memberikan hasil terbaik terhadap bobot tongkol jagung berkelobot per tongkol dibandingkan perlakuan dosis pupuk lainnya. Hal ini diduga aplikasi dosis pupuk $0 \%$ dosis rekomendasi dan $50 \%$ dosis rekomendasi belum mampu menyediakan kebutuhan unsur hara yang optimal bagi pembentukkan tongkol jagung berkelobot per tongkol. Salah satu unsur hara yang berpengaruh terhadap bobot tongkol jagung adalah unsur $P$.

Pada penelitian ini aplikasi pemupukan TSP dilakukan seminggu sebelum tanam, sehingga ketersediaan unsur $\mathrm{P}$ di dalam tanah terpenuhi sampai panen tanaman jagung manis. Menurut Haryani (2000) fosfor merupakan salah satu hara makro yang sangat vital bagi tanaman, karena merupakan sumber energi untuk pertumbuhan tanaman. Wahyudin dkk. (2007), ketersediaan P yang tinggi dalam larutan tanah akibat pemupukan $P$ memungkinkan penyerapan hara yang tinggi oleh tanaman.

\section{Bobot Tongkol Jagung Berkelobot Per Plot}

Hasil sidik ragam menunjukkan, aplikasi pupuk anorganik berpengaruh nyata terhadap parameter bobot tongkol jagung berkelobot per plot. Perlakuan dosis $100 \%$ rekomendasi menghasilkan rata-rata bobot tongkol jagung berkelobot per plot tertinggi yaitu $12,150 \mathrm{~kg}$, tetapi tidak berbeda nyata terhadap perlakuan $50 \%$ dosis rekomendasi dengan rata-rata $10,827 \mathrm{~kg}$, namun berbeda nyata dengan aplikasi $0 \%$ dosis rekomendasi dengan ratarata $9,217 \mathrm{~kg}$ (Tabel 6).

Tabel 6. Bobot Tongkol Jagung Berkelobot Per Plot (kg)

\begin{tabular}{cc}
\hline Perlakuan & Bobot Tongkol Jagung Berkelobot Per Plot $(\mathrm{kg})$ \\
\hline Pola Tanam (T) & 10,896 \\
T1 & 10,567 \\
T2 & $9,217^{\mathrm{b}}$ \\
Pupuk Anorganik (A) & $10,827^{\mathrm{ab}}$ \\
A0 & $12,150^{\mathrm{a}}$ \\
A1 & \\
A2 & Superskrip yang berbeda pada lajur yang sama menunjukkan perbedaan yang nyata pada uji \\
& DMRT 5\%.
\end{tabular}

Tabel 6 menunjukkan bahwa aplikasi pemupukan $50 \%$ dan $100 \%$ dosis rekomendasi memberikan hasil bobot tongkol jagung berkelobot per plot yang sama baiknya. Diduga aplikasi pemupukan $50 \%$ dosis rekomendasi telah mampu menyediakan unsur hara optimal yang dibutuhkan tanaman jagung manis terhadap tongkol jagung berkelobot per plot, sehingga lebih ekonomis dan efisien, serta ekologis. Ridwan (2011), pengurangan dosis pupuk anorganik (NPK) dari $100 \%$ dosis menjadi $50 \%$ dosis pada penelitian tidak mengakibatkan penurunan efisiensi penggunaan hara, pertumbuhan, maupun produksi tanaman cabai, bahkan terdapat kecenderungan mengalami peningkatan.

Pembentukkan tongkol jagung sangat dipengaruh oleh unsur hara yang diserap oleh akar tanaman di dalam tanah melalui pemupukan yang dilakukan. Tidak tersedianya unsur hara bagi tanaman jagung manis akan mengakibatkan bobot tongkol tidak optimal. Menurut Maisaroh (2013) perlakuan pupuk standar dan kombinasi dengan pupuk organik berpengaruh nyata pada rataan bobot tongkol dengan kelobot dan bobot brangkasan. Herliana dkk. (2015) menyatakan dosis pemupukan berpengaruh nyata terhadap panjang dan bobot tongkol jagung manis.

\section{Bobot Tongkol Jagung Tanpa Kelobot Per Tongkol}

Hasil sidik ragam menunjukkan, bahwa perlakuan aplikasi pupuk anorganik berpengaruh sangat nyata terhadap parameter bobot tongkol jagung tanpa kelobot per 
tongkol. Perlakuan $100 \%$ dosis rekomendasi menghasilkan rata-rata bobot tongkol jagung tanpa kelobot per tongkol tertinggi yaitu $290,758 \mathrm{~g}$, tetapi tidak berbeda nyata terhadap aplikasi $50 \%$ dosis rekomendasi dengan ratarata $262,215 \mathrm{~g}$, namun berbeda nyata dengan $0 \%$ dosis rekomendasi (kontrol) dengan ratarata 212,707 g (Tabel 7).

Tabel 7. Bobot Tongkol Jagung Tanpa Kelobot Per Tongkol (g)

\begin{tabular}{cc}
\hline Perlakuan & Bobot Tongkol Jagung Tanpa Kelobot Per Tongkol $(\mathrm{g})$ \\
\hline Pola Tanam (T) & 267,643 \\
T1 & 242,810 \\
T2 & $212,707^{\mathrm{b}}$ \\
Pupuk Anorganik (A) & $262,215^{\mathrm{a}}$ \\
A0 & $290,758^{\mathrm{a}}$ \\
A1 & \\
A2 & Superskrip yang berbeda pada lajur yang sama menunjukkan perbedaan yang nyata pada uji \\
& DMRT 5\%.
\end{tabular}

Tabel 7 menunjukkan, bahwa aplikasi pemupukan $50 \%$ dosis rekomendasi memberikan hasil bobot tongkol jagung tanpa kelobot per tongkol yang sama baiknya dengan perlakuan dosis $100 \%$ rekomendasi. Diduga proporsional pemupukan pada tanaman jagung manis telah terpenuhi dengan baik di dalam tanah walaupun hanya 50\% dosis rekomendasi. Menurut Wargiono (2003) pemupukan tidak berimbang seperti N, NP dan NK atau NPK dengan takaran tidak proporsional dapat menurunkan ketersediaan hara di tanah. Hasil penelitian Wahyudin dkk, (2007) menunjukkan, bahwa perlakuan jenis pupuk SP-36 dengan dosis $50 \%$ dari anjuran dengan pengaplikasian pupuk hayati MPF sebanyak 1 kali pada saat tanam, cenderung lebih baik dan lebih efisien terhadap hasil tanaman jagung dibandingkan dengan perlakuan lain.

\section{Bobot Tongkol Jagung Tanpa Kelobot Per Plot}

Berdasarkan hasil sidik ragam menunjukkan, bahwa perlakuan pupuk anorganik berpengaruh nyata terhadap bobot tongkol jagung tanpa kelobot per plot. Perlakuan $100 \%$ dosis rekomendasi (A2) menghasilkan rata-rata bobot tongkol jagung tanpa kelobot per plot tertinggi yaitu $9,650 \mathrm{~kg}$, tetapi tidak berbeda nyata terhadap aplikasi $50 \%$ dosis rekomendasi dengan rata-rata $8,700 \mathrm{~kg}$, namun berbeda nyata dengan $0 \%$ dosis rekomendasi (kontrol) dengan rata-rata $7,550 \mathrm{~kg} \quad$ (Tabel 8).

Tabel 8. Bobot Tongkol Jagung Tanpa Kelobot Per Plot (kg)

\begin{tabular}{cc}
\hline Perlakuan & Bobot Tongkol Jagung Tanpa Kelobot Per Plot $(\mathrm{kg})$ \\
\hline Pola Tanam (T) & 8,789 \\
T1 & 8,478 \\
T2 & $7,550^{\mathrm{b}}$ \\
Pupuk Anorganik (A) & $8,700^{\mathrm{ab}}$ \\
A0 & $9,650^{\mathrm{a}}$ \\
A1 & \\
A2 & Superskrip yang berbeda pada lajur yang sama menunjukkan perbedaan yang nyata pada uji \\
& DMRT 5\%.
\end{tabular}

Tabel 8 menunjukkan bahwa aplikasi pemupukan $50 \%$ dosis rekomendasi memberikan hasil bobot tongkol jagung tanpa kelobot per plot yang berbeda tidak nyata dengan perlakuan dosis $100 \%$ rekomendasi. Hal ini berarti dosis pemupukan $50 \%$ rekomendasi lebih efektif dan efisiensi dalam pemupukan tanaman jagung manis. Bobot tongkol jagung selain dipengaruhi oleh unsur hara $\mathrm{P}$ juga dipengaruhi unsur lain yaitu $\mathrm{N}$ dan $\mathrm{K}$.

Hasil penelitian Jumini dkk. (2011) menunjukkan, bahwa kombinasi dosis pupuk
$\mathrm{N}$, $\mathrm{P}$ dan $\mathrm{K}$ berpengaruh sangat nyata terhadap berat tongkol berkelobot, berat tongkol tanpa kelobot dan berat tongkol tanpa kelobot per ha serta berpengaruh nyata terhadap tinggi tanaman jagung pada umur 30 dan 45 hari setelah tanam dan panjang tongkol, namun berpengaruh tidak nyata terhadap diameter tongkol jagung manis. Suratmini (2009) pupuk nitrogen secara tunggal berpengaruh sangat nyata terhadap bobot segar dan bobot kering oven tongkol komersial. 
Bobot Basah Tajuk Tanaman

Hasil sidik ragam menunjukkan bahwa perlakuan pola tanam jagung manis dan aplikasi pupuk anorganik serta interaksi keduanya tidak berpengaruh nyata terhadap parameter bobot basah tajuk tanaman jagung manis (Tabel 9).

Tabel 9. Bobot Basah Tajuk Tanaman (g)

\begin{tabular}{cc}
\hline Perlakuan & Bobot Basah Tajuk Tanaman $(\mathrm{g})$ \\
\hline Pola Tanam (T) & 393,816 \\
T1 & 349,978 \\
T2 & 332,425 \\
Pupuk Anorganik (A) & 392,295 \\
A0 & 390,970 \\
A1 & \\
A2 & \\
\hline
\end{tabular}

Tabel 9 menunjukkan bahwa perlakuan pola tanam jagung manis secara monokultur maupun tumpangsari dengan tanaman sela pegagan dan aplikasi pupuk anorganik baik dengan dosis $0 \%, 50 \%$ maupun $100 \%$ rekomendasi, menunjukkan hasil yang tidak signifikan terhadap bobot basah tajuk tanaman. Hasil ini menandakan, bahwa penanaman pegagan sebagai tanaman sela dan adanya aplikasi pupuk anorganik pada tanaman jagung manis, tidak mengakibatkan penurunan hasil bobot basah tajuk tanaman. Adanya simbiosis fungi mikoriza arbuskula (FMA) yang berasosiasi dengan tanaman pegagan, diduga turut berperan dalam transfer hara kedua tanaman, sehingga berdampak terhadap bobot basah tanaman jagung manis.

Menurut Hartoyo dkk. (2015) simbiosis FMA dengan tanaman tertentu dikatakan efektif jika menghasilkan pengaruh bagi tanaman, misalnya peningkatan pertumbuhan dan biomassa. Penelitian hampir serupa telah dilakukan Rumambi (2012) pada tanaman kacang hias $A$. pintoi yang bersimbiosis dengan FMA, yang ditanam secara tumpangsari dengan tanaman jagung dan sorgum. Hasil penelitiannya menunjukkan, bahwa simbiosis FMA dan $A$. pintoi dapat mentransfer nutrien dan senyawa-senyawa lain ke tanaman jagung atau sorgum untuk meningkatkan pertumbuhan dan produksi tanaman jagung dan sorgum yang berkualitas. A. pintoi yang diinokulasi FMA banyak memberikan keuntungan pada tanaman tumpangsari baik dalam hal nutrisi maupun dalam hal peningkatan senyawa-senyawa metabolit sekunder untuk peningkatan aktivitas antioksidan dan bioproteksi terhadap hama dan penyakit.

\section{KESIMPULAN}

\section{Kesimpulan}

Pola tanam jagung manis yang ditanam dengan tanaman sela pegagan memberikan hasil yang sama baiknya dengan pola tanam jagung manis monokultur, kecuali pada parameter jumlah daun umur 6 MST yang menghasilkan jumlah daun lebih banyak pada pola tanam monokultur. Aplikasi pupuk anorganik 50\% dosis rekomendasi (Urea 250 $\mathrm{kg} / \mathrm{ha}+\mathrm{TSP} 175 \mathrm{~kg} / \mathrm{ha}+\mathrm{KCl} 150 \mathrm{~kg} / \mathrm{ha}$ ) meningkatkan hasil bobot tongkol jagung berkelobot per plot, bobot tongkol jagung tanpa kelobot per tongkol dan bobot tongkol jagung tanpa kelobot per plot. Tidak terdapat interaksi antara pola tanam dengan pupuk anorganik terhadap pertumbuhan dan hasil tanaman jagung manis.

\section{DAFTAR PUSTAKA}

Aidid, I.U. 2012. Penerapan Standar Operasional Produksi untuk Meningkatkan Pertumbuhan, Produksi dan Kualitas Pisang Tanduk (Musa sp., AAB Group). Skripsi. Fakultas Pertanian. IPB. Bogor.

Allen, M.F and E.B. Allen. 1992. Development of Mycorrhizal Patches in a Successional Arid Ecosystem. pp 164170. In: Read D.J., D.H. Lewis., A.H. Fitter, and I.J. Alexander. Mycorrhizas in Ekosystem. CBA International. Wallingford, UK.

Balai Besar Penelitian dan Pengembangan Sumberdaya Lahan Pertanian (BBPSLP). 2011. Rencana Strategis Penelitian dan Pengembangan Sumberdaya Lahan Pertanian 20102014. Badan Penelitian dan Pengembangan Pertanian. Jakarta. 59 hal.

Bilman, W.S. 2001. Analisis Pertumbuhan Tanaman Jagung Manis (Zea mays Saccharata), Pergeseran Komposisi Gulma pada Beberapa Jarak Tanam. Jurnal IImu-ilmu Pertanian Indonesia, 3(1): 25-30.

Darwati, I., E.R. Pribadi dan Makmun. 2012. Budidaya dan Pasca Panen Pegagan 
(Centella asiatica). Balai Penelitian Tanaman Rempah dan Obat (Balittro). Bogor. 2p.

Farida, R. 2011. Pengaruh Pemberian Cendawan Mikoriza Arbuskula (CMA) dan Dosis Pupuk Kandang Ayam terhadap Pertumbuhan dan Produksi Jagung (Zea mays L.). Skripsi. Fakultas Pertanian. IPB. Bogor.

Hartoyo, B. 2012. Efektivitas Fungi Mikoriza Arbuskula pada Penggunaan Pupuk Fosfor Alami dan Pengaruhnya terhadap Pertumbuhan, Biomassa dan Produksi Asiatikosida Pegagan (Centella asiatica (L.) Urban) di Andosol. Disertasi. Sekolah Pascasarjana. IPB. Bogor.

Hartoyo, B. O. Trisilawati dan M. Ghulamahdi. 2015. Tanggap Pertumbuhan dan Biomasa Pegagan (Centella asiatica (L.) Urban) pada Aplikasi Fungi Mikoriza Arbuskula dan Pemupukan di Tanah Andosol. Bul. Littro, 26(2): 87-98.

Herliana, O., Atang dan I. Ujiono. 2015. Pengaruh Dosis Pemupukan pada Sistem Tanam Tumpangsari terhadap Pertumbuhan dan Hasil Jagung Manis Dan Kedelai. Jurnal Agroekotek, 7(2): 129-137.

Haryani, N. Y. 2000. Pengaruh Inokulasi Dua Spesies Cendawan Mikoriza Arbuskula dan Pemupukan Fosfor terhadap Pertumbuhan dan Serapan Fosfor Tajuk Kelapa Sawit (Elaeis guineensis Jacq.) di Pembibitan. Skripsi. Fakultas Pertanian. IPB. Bogor.

Hasanah, I. 2017. Pengaruh Dosis Pupuk $(\mathrm{N}, \mathrm{P}, \mathrm{K})$ dan Formulasi Pupuk Hayati terhadap Produksi dan Mutu Benih Jagung Hibrida di Lapang. Skripsi. Fakultas Pertanian. IPB. Bogor.

Ingleby K., J. Wilson., R.C. Munro and S. Cavers. 2007. Mycorrhizas in Agroforestry: Spread and Sharing of Arbuscular Mycorrhizal Fungi Between Trees and Crops: Complementary use of Molecular Microscopic Approaches. Plant Soil, 294: 125-136.

Jumini., Nurhayati dan Murzani. 2011. Efek Kombinasi Dosis Pupuk N P K dan Cara Pemupukan terhadap Pertumbuhan dan Hasil Jagung Manis. J. Floratek, 6: 165170.

Maisaroh. 2013. Efektivitas Pupuk Organik terhadap Pertumbuhan, Produksi dan Kadar Hara NPK Daun Tanaman Jagung Manis di Latosol Darmaga. Skripsi. Fakultas Pertanian. IPB. Bogor.

Marlina, N., Rosmiah dan Marlina. 2016. Pemanfaatan Jenis Pupuk Anorganik terhadap Jagung Manis (Zea mays
Saccharata Sturt.) di Lahan Lebak. pp. 428-433. In: Prosiding Seminar Nasional Lahan Sub Optimal. Palembang, 20-21 Oktober 2016.

Martono, B. 2011. Keragaman dan Tanggap Pertumbuhan, serta Produksi Asiatikosida Pegagan (Centella asiatica (L.) Urban) pada Ketinggian Tempat dan Naungan yang Berbeda. Disertasi. Sekolah Pascasarjana. IPB. Bogor.

Mulyaningsih, S dan B. Hariyono. 2013. Pengaruh Macam Tanaman Sela terhadap Pertumbuhan dan Hasil Jarak Pagar (Jatropha curcas L.) Hasil Rehabilitasi Tahun Ketiga. Buletin Tanaman Tembakau, Serat dan Minyak Industri, 5(2): 69-77.

Mayadewi, N.N.A. 2007. Pengaruh Jenis Pupuk Kandang dan Jarak Tanam terhadap Pertumbuhan Gulma dan Hasil Jagung Manis. Agritrop, 26(4): 153-159.

Nazirah, L. 2014. Kajian Pertumbuhan dan Produksi Berbagai Varietas Pagi Gogo (Oryza sativa L.) terhadap Pemupukan Majemuk NPK di Aceh. pp. 15-22. In: Prosiding Seminar Regional Wilayah Sumatera. Banda Aceh, 2-3 September 2014.

Pangaribuan, N. 2014. Penjaringan Cendawan Mikoriza Arbuskula Indigenous dari Lahan Penanaman Jagung dan Kacang Kedelai pada Gambut Kalimantan Barat. Jurnal Agro, 1(1): 50-60.

Pusat Data dan Sistem Informasi Pertanian. 2015. Outlook Komoditas Pertanian Tanaman Pangan Jagung. Pusat Data dan Sistem Informasi Pertanian Kementerian Pertanian. Jakarta. 82 hal.

Rumambi, A. 2012. Penyediaan Pakan Berkelanjutan Melalui Inokulasi Fungi Mikoriza Arbuskula dan Aplikasi Fospat Alam pada Arachis pintoi cv Amarillo dalam Tumpang Sari dengan Jagung (Zea mays L) atau Sorgum (Sorghum bicolor L, Moench). Disertasi. Sekolah Pascasarjana. IPB. Bogor.

Rajapakse S. and J.C. Miller. 1992. Method for Studying Vesicular-Arbuscular Mycorrhizal Root Colonization and Related Root Physical Properties. Methods Microbiol 24: 302-316.

Ridwan. 2011. Pengayaan Pupuk Organik dengan Pupuk Hayati untuk Meningkatkan Efisiensi Penggunaan Hara, Pertumbuhan dan Produksi Tanaman Cabai. Tesis. Sekolah Pascasarjana. IPB. Bogor.

Surtinah. 2012. Korelasi Antara Waktu Panen dan Kadar Gula Biji Jagung Manis (Zea 
mays Saccharata Sturt). Jurnal IImiah Pertanian, 9(1): 1-6.

Suratmini, P. 2009. Kombinasi Pemupukan Urea dan Pupuk Organik pada Jagung Manis di Lahan Kering. Penelitian Pertanian Tanaman Pangan, 28(2): 8388.

Santoso, M.B. 2004. Efisiensi Energi dan Produktivitas pada Tumpangsari Jagung Manis (Zea mays Saccharata Sturt) dan Berbagai Kerapatan Kacang Hijau (Vigna radiata L.) dengan Pengolahan Tanah yang Berbeda. Tesis. Sekolah Pascasarjana. IPB. Bogor.

Turmudi, E. 2002. Kajian Pertumbuhan dan Hasil Tanaman dalam Sistem
Tumpangsari Jagung dengan Empat Kultivar Kedelai pada Berbagai Waktu Tanam. Jurnal Ilmu-ilmu Pertanian Indonesia, 4(2): 89-96.

Wahyudin, A., B.N. Fitriatin., F.Y. Wicaksono., Ruminta dan A. Rahadiyan. 2007. Respon Tanaman Jagung (Zea mays L.) Akibat Pemberian Pupuk Fosfat dan Waktu Aplikasi Pupuk Hayati Mikroba Pelarut Fosfat pada Ultisols Jatinangor. Jurnal Kultivasi, 16(1): 246-254.

Wargiono, J. 2003. Pemupukan NPK dan Sistem Tanam Ubikayu pada Tanah Ultisol Lampung. Penelitian Pertanian Tanaman Pangan, 22(2): 114-120 